\title{
The Effect of Surface Preparation on Friction and Wear Behaviour of DLC Coated X42Cr13 Plastic Mold Tool Steel
}

\author{
SHIRAZ R. AHMED SIDDIQUI, University of Miskolc, \\ Institute of Materials Science and \\ Technology, Miskolc, Hungary \\ ANDREA T. SZILAGYINE BIRO, University of Miskolc, \\ Institute of Materials Science and \\ Technology, Miskolc, Hungary \\ MARIA R. BERKES MAROS, University of Miskolc, \\ Institute of Materials Science and \\ Technology, Miskolc, Hungary
}

\author{
Original scientific paper \\ UDC: 621.785.53:669.14.09 \\ DOI: 10.5937/tehnika1902175S
}

The aim of the presented research work is to investigate the effect of different surface preparationglass bead blasting $(G B B)$ and polishing $(P)$ on the friction behaviour of the duplex treated DiamondLike Carbon (DLC) coated X42Cr13 Plastic Mold Tool Steel. Duplex treatment involved plasma nitriding followed by Plasma Enhanced Chemical Vapour Deposition (PECVD) and the surface preparation was accomplished after the nitriding prior to PECVD coating. The friction behaviour was studied using ball-on-disc wear test defining the friction coefficient vs. sliding distance curves, the morphology of the wear tracks was investigated by optical microscope. Based on the presented experimental results it is established that GBB and polishing procedures have measurably different influence on the frictional and wear behaviour of the superhard upper layer, resulting in lower value of friction coefficient, less wear debris and better adhesion of the coating to the substrate in case of GBB operation. In addition, some test results are presented for uncoated, simply nitrided samples to emphasize the advantage of duplex treatment on the wear/friction behaviour the investigated tool material.

Key words: duplex surface treatment, plasma nitriding, DLC coating, ball-on-disc test

\section{INTRODUCTION}

Surface engineering is a field related to science and technology of modifying surface characteristics as per requirements to enhance the life of the engineering products (mechanical components) while operating. The broad classification of surface engineering can be done in two groups: surface modification and surface coating. In surface modification the microstructure, thus the properties of the surface and near surface regions are changed by the application of different heat treatment techniques, whereas during surface coating a new layer is added on to the substrate [1].

Author's address: Shiraz Ahmed Siddiqui, University of Miskolc, Institute of Materials Science and Technology, Miskolc, Egyetem street 1. H-3515, Hungary

e-mail: shiraz.ahmed@uni-miskolc.hu

Paper received: 12.02.2019.

Paper accepted: 05.03.2019.
Duplex heat treatment can be defined as the combination of two or more surface modification techniques applied to produce a multi-layer composite surface structure to provide better wear, friction resistance [[2], [3]]. In the presented research work the applied treatment is a combination of plasma nitriding and Plasma Enhanced Chemical Vapour Deposition (PECVD) producing Diamond-Like Carbon (DLC) coating. The advantage of using plasma nitriding is that there is no porosity in the surface layer, diffusion rate of nitrogen atoms into the surface is higher than in case of gas nitriding and it is a well-controlled process [[4] - [7]]. DLC top layers are widely used as tribological coatings for mechanical components that are prone to abrasive wear and high degree of kinetic friction, for instance compressor gears, bearings and various injection components [[8], [9]].

Surface preparation is an essential first stage treatment of the substrate before applying the coating process. The performance of the coating is significantly influenced by its ability to adhere properly to the 
substrate material. The presence of even small quantities of contaminants such as dirt, grease, oxides etc. can physically impair and reduce coating adhesion to the substrate. Hence, it is a well-established fact that the correct surface preparation is one of the most important factor affecting the combined behaviour of the substrate and coating system [[10], [11]].

The basic objective of the current paper is to show the difference in the friction behaviour of a simply nitrided and duplex treated plastic mold steel, as well as to analyse the effect of different surface preparation methods on the wear/friction behaviour of the duplex treated tool surfaces. The reported work is the part of a more comprehensive investigation analysing the effect of different factors on the wear and friction behaviour of this tool steel [[12], [13]].

\section{INVESTIGATED MATERIAL}

The base material of the investigated specimens is a high alloy plastic mold tool steel X42Cr13/W (DIN) Nr. 1.2083. The standard chemical composition is given by Table 1 .

Table 1. Standard chemical composition in wt\%; EN ISO 4957:2001, DIN 17350 (1980)

\begin{tabular}{|l|l|l|l|l|l|l|}
\hline $\mathrm{C}$ & $\mathrm{Si}$ & $\mathrm{Mn}$ & $\mathrm{P}$ & $\mathrm{S}$ & $\mathrm{Cr}$ & $\mathrm{Fe}$ \\
\hline $0.38-$ & $\max$ & $\max$ & $\max$ & $\max$ & $12.00-$ & Bal. \\
0.45 & 1.0 & 1.0 & 0.030 & 0.030 & 13.50 & \\
\hline
\end{tabular}

Each sample were bulk heat treated, i.e. precipitation hardened. The duplex treatment consisted of plasma nitriding and PECVD produced DLC coating.

The nitriding process was accomplished at two different temperatures: $520^{\circ} \mathrm{C}$ and $550^{\circ} \mathrm{C}$, with uniform holding time of 8 hours, voltage of $600 \mathrm{~V}$, and pressure of 2 mbar.

The source of nitrogen was decomposed ammonia $\left(\mathrm{N}_{2}: \mathrm{H}_{2}=1: 3\right)$. The coating material was DLC, with WC underlayer, i.e. it was a multilayer coating, with the following elements: $\mathrm{WC}+\mathrm{a}-\mathrm{C}: \mathrm{HW}+\mathrm{a}-\mathrm{C}: \mathrm{H}$.

The coating was produced by PECVD process, combining the advantage of PVD processes performed at low temperature and CVD processes resulting in stronger atomic bonding.

\section{EXPERIMENTAL WORK}

\subsection{Characterization of test samples}

The test samples were disc shaped specimens with dimension of $\phi 50 \mathrm{~mm} \times 10 \mathrm{~mm}$. The calculated layer thickness of the WC/DLC coating was $2.35 \mu \mathrm{m}$ based on Calotest ball cratering measurements [14].

The samples of the reference group were uncoated, while effect of surface preparation prior to PECVD coating was analysed on the duplex treated samples, consisted of the above described treatments.

\subsection{Surface preparation of the duplex treated samples}

The surface of the precipitation hardened and plasma nitrided substrate material was differently prepared before the PECVD coating procedure.

The investigated surface preparation processes were polishing (P) and glass bead blasting (GBB) carried out prior to the coating. The characteristics of the surface preparation (SP) methods, and the related sample notation are given in Table 2 .

Table 2. Sample notation and characteristics of the surface preparation (SP) prior to PECVD

\begin{tabular}{|l|l|ll|l|}
\hline Sample notation & Steps of surface preparation & Auxiliary material & Aim of the preparation step \\
\hline P+PECVD & $\begin{array}{l}\text { 1. Grinding } \\
\text { 2. Polishing }\end{array}$ & $\begin{array}{l}1 . \\
2 .\end{array} \quad \begin{array}{l}\text { Grinding papers; } \\
\mathrm{Al}_{2} \mathrm{O}_{3} \text { suspension }\end{array}$ & $\begin{array}{l}\text { 1. cleaning after nitriding } \\
\text { 2. smoothing }\end{array}$ \\
\hline GBB+PECVD & $\begin{array}{l}\text { 1. Grinding } \\
\text { 2. Glass Bead Blasting }\end{array}$ & $\begin{array}{l}\text { - } \begin{array}{l}\text { Grinding papers } \\
\mathrm{mm}\end{array} \\
\mathrm{SiO}_{2} \text { beads, } \phi 0,1\end{array}$ & $\begin{array}{l}\text { 1.+2.: two-step cleaning prior to } \\
\text { PECVD }\end{array}$ \\
\hline
\end{tabular}

\subsection{Ball-on-disc test}

To study the wear / friction behaviour of the samples having different surface preparation ball-on disc test was carried out using a UNMT-1 tester (CETR, USA).

During this test the friction coefficient $(\mu)$ was recorded using a computer software. The applied wear test parameters are summarized in Table 3 . The total sliding distance (L) was chosen based on $360 \mathrm{~m}$ pretests, by defining the minimum run, leading to steady state friction coefficient.
Table 3. Test parameters of the ball-on-disc tests

\begin{tabular}{|l|l|}
\hline Parameter & Value \\
\hline Material of the ball & $\mathrm{SiC}$ \\
\hline Diameter of the ball & $\phi 6 \mathrm{~mm}$ \\
\hline Normal load & $\mathrm{F}=90 \mathrm{~N}$ \\
\hline Total sliding distance & $\mathrm{L}=180 \mathrm{~m}$ \\
\hline Radius of the wear track & $\mathrm{R}=3 \mathrm{~mm}$ \\
\hline
\end{tabular}




\section{RESULTS AND DISCUSSION}

4.1. Comparison of the effect of the different surface preparation prior to PECVD on the friction behaviour of the coated samples having a substrate nitrided at $520^{\circ} \mathrm{C}$

Figure 1. illustrate the friction coefficient $(\mu)$ vs. sliding distance (L) curves for coated samples having identical substrate material (nitrided at $520{ }^{\circ} \mathrm{C}$ ), but different surface preparation (P and GBB) procedures. As a reference, the $(\mu)-(L)$ curve for the similarly treated, but uncoated substrate material is also shown. In Figure 1, it can be observed that the friction coefficient curve for the glass bead blasted $\mathrm{N}\left(520^{\circ} \mathrm{C}\right)+$ GBB + PECVD sample has the most smooth and uniform character with no significant variation in magnitude, and reaching the steady state value relatively soon.

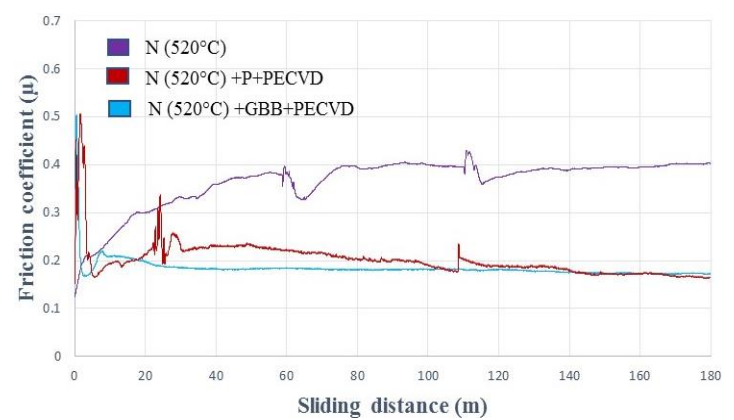

Figure 1 - Comparison of the friction coefficient curves obtained for samples having substrate, nitrided at $T=520^{\circ} \mathrm{C}$ with differently prepared surfaces below the PECVD coating, and without coating

The friction coefficient curve for the sample, denoted by $\mathrm{N}\left(520^{\circ} \mathrm{C}\right)+\mathrm{P}+\mathrm{PECVD}$, i.e. that was polished before applying the PECVD coating shows a regular variations in $\mu$, with regular peaks on the curve. In addition, the slope for this curve is varying along the entire sliding distance, approaching the steady-state friction coefficient value measured on the GBB prepared coated surface. The possible reason for the more visible variation of the friction coefficient can be the presence of some debris originating either the sliding counterpart, i.e. $\mathrm{SiC}$ ball or the broken coating material. The higher tendency of the DLC coating to break, when the substrate is polished, can be explained by the fact that at the relatively low nitriding temperature $\left(520^{\circ} \mathrm{C}\right)$ a very thin compound layer forms on the surface of the substrate material, which is easily removed by the polishing operation. Thus, the underlaying softer material provides less support for the coating, which will have higher tendency to damaging and to be detached. For both coated samples, independently of the surface preparation method the closely identical values of the friction coefficient at the final stage of the total sliding distance suggests that similar steady state conditions can be develop during the friction process, allowing the DLC layer to influence favourably the friction process, supposedly acting as some lubricating material.The friction coefficient curve obtained for the uncoated sample basically differs from those obtained for the coated discs. On the one hand, the measured friction coefficient values are the highest, and are continuously increasing throughout the entire sliding distance, showing much more pronounced variation in magnitude.

The worse friction behaviour of the uncoated surface is explained by the fact that the nitrided surface layer of lower hardness, compared to the DLC layer, is more prone to cracking and due to the continuously forming hard wear debris particles (forming third body particles) has much lower resistivity to abrasive wear.

The optical microscopic pictures of the wear tracks (Figure 2.) created on the DLC coatings with different surface preparation correspond to the friction coefficient curves.

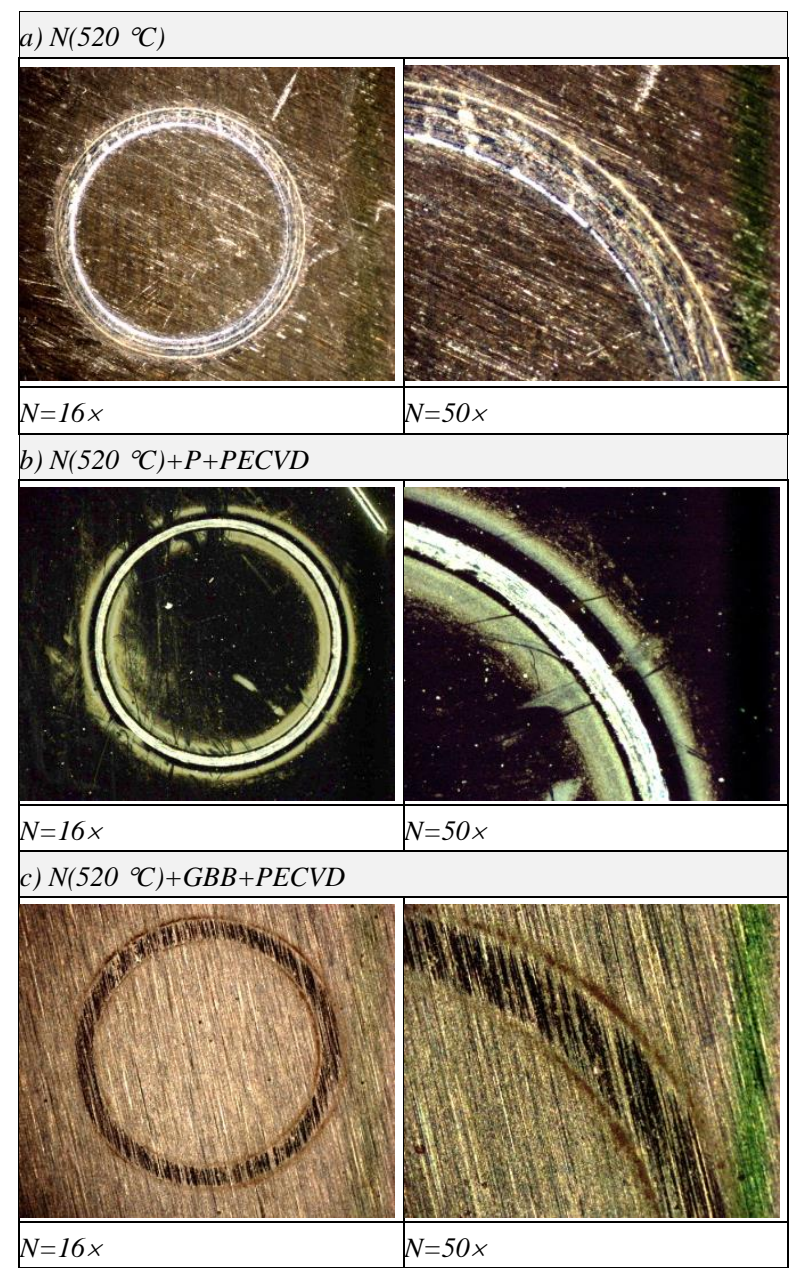

Figure 2 - Optical microscopic pictures of the wear tracks. Uncoated (a); coated ( $b$ and $c$ ) sample 
The least damage can be seen on the coated surface with GBB preparation, while the most intensive damages can be observed on the uncoated, nitrided surface, for which the friction coefficient curve represents the highest friction coefficient values and even more unequal running of the curve.

Analysing the reason behind this observation a possible explanation can be the unique surface texture produced by the glass bead blasting process, prior to coating. It is supposed that the more favourable friction behaviour can be originated from the better surface conditions for the coating to co-act with the substrate, and remaining intact during the entire wear test

The supposed „better conditions ${ }^{\text {ee }}$ may involve on the one hand compressive residual stresses in the outermost surface layer due to the GBB process, on the other hand an improved micro geometrical, mechanical and physico-chemical properties of the surface, like higher microhardness, lower average roughness, less contamination and higher chemical resistivity providing better adhesion for DLC layer to the substrate. Thus, based on the above analyses we may conclude that the glass bead blasting process as compared with the polishing can provide more advantageous surface conditions from the point of view of integrity of the PECVD coating and its coherency with the substrate.

\subsection{Comparison of the effect of the different surface preparation prior to PECVD on the \\ friction behaviour of the coated samples having substrate nitrided at $550^{\circ} \mathrm{C}$}

The friction coefficient curves for the uncoated and coated the samples with substrate nitride at the higher $\left(550{ }^{\circ} \mathrm{C}\right)$ temperature are shown in Figure 3.

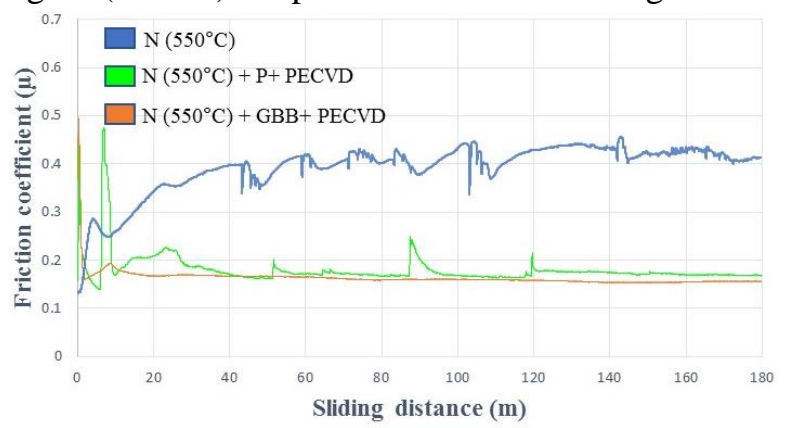

Figure 3 - Comparison of the friction coefficient curves obtained for samples having nitrided ( $T=550$ $\left.{ }^{\circ} \mathrm{C}\right)$ substrates and differently prepared surfaces below the PECVD coating

Regarding the curves for the coated samples with different surface preparations it is seen that their run is nearly identical in terms of the magnitude of the friction coefficient values, that was slightly lower, than those obtained with substrates nitride at the lower temperature.
At the same time, the curve obtained for the coated sample with GBB prepared substrate $\left(\left(\mathrm{N} 550^{\circ} \mathrm{C}\right)+\mathrm{GBB}+\mathrm{PECVD}\right)$ is significantly smoother, and there is no significant variation in the value of $\mu$ along the entire sliding distance which clearly signifies a good friction behaviour of the DLC coating.

In contrast, the related curve obtained with the polished substrate $\left(\left(\mathrm{N} 550^{\circ} \mathrm{C}\right)+\mathrm{P}+\mathrm{PECVD}\right)$ shows frequently and regularly repeated peaks in the friction coefficient values along the entire sliding distance. This could be again, due to the presence of some debris and the possibility that the coating was partially detached as a result of which the friction coefficient value could no longer be stable. The probability of an intensive debris formation is highly supported by the sharp peak appearing at the beginning of the related friction coefficient curve, that is indicative of the early damage and detachment of the DLC coating on this type of specimen. As a consequence, polishing the substrate surface didn't provide better results than the glass bead blasting. It is also important that both friction coefficient curves obtained for the coated samples showed a continuously decreasing character, suggesting a lubricated friction phenomenon.

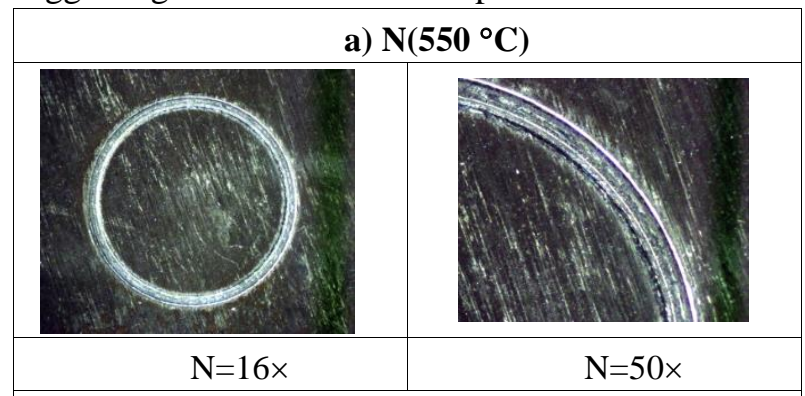

b) $\mathrm{N}\left(550^{\circ} \mathrm{C}\right)+\mathrm{P}+\mathrm{PECVD}$

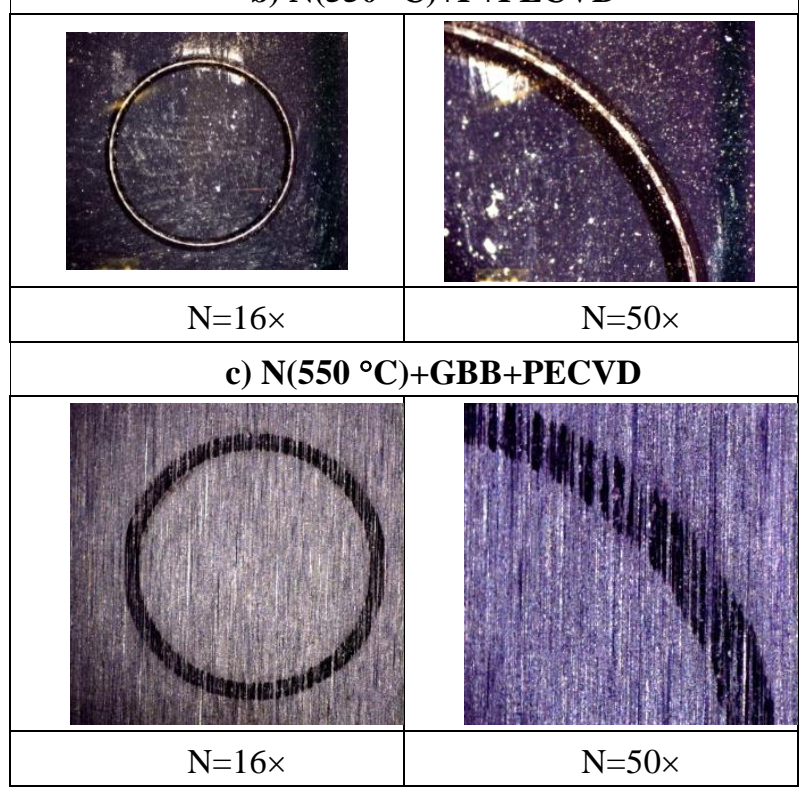

Figure 4 - Optical microscopic pictures of the wear tracks. Uncoated (a); coated ( $b$ and $c)$ samples 
In case of the uncoated (simply nitrided) sample there is an abrupt increase of $\mu$, right from the beginning of the wearing process and an increasing slope can be observed along the entire curve, which indicates a poor frictional resistivity of the surface. The optical microscopic pictures of the wear tracks are shown in Figure 4

Similarly, to the formerly analysed cases, when the substrates were nitrided at lower temperature, the influence of the surface preparation method on the friction behaviour seems to be very similar, independently on this parameter. The friction coefficient curves and the wear track morphology are in good accordance, i.e. in case of the coated sample having polished substrate, when the friction coefficient curve indicates abrasive particles to be present during friction, the wear track is deeper, and the damage of the surface layer is greater. The highest injury of the worn surface is observed in case of the wear track formed on the uncoated specimen.

Altogether the best frictional performance is provided by the sample which was glass bead blasted before making the PECVD produced DLC layer. This case the coating remained intact and kept in touch with the substrate, i.e. the integrity of the DLC layer could be maintained throughout the wear test.

\subsection{Summary of the test results}

Based on the executed pin-on-disc tests and wear track morphological investigations, we can establish that glass bead blasting surface preparation procedure resulted in better surface conditions and lower friction coefficient as compared to polishing the samples before applying PECVD coating of DLC. With the view of integrity of DLC layer and its coherency with the substrate, using GBB provides smooth and uniform friction coefficient curve in both cases, i.e. nitriding the substrate at $520{ }^{\circ} \mathrm{C}$ and $550{ }^{\circ} \mathrm{C}$.

The most suitable combination was obtained when glass bead blasting process was carried out on substrate nitrided at $550{ }^{\circ} \mathrm{C}$, prior to PECVD coating.

\section{CONCLUSIONS}

Based on the accomplished comparative study on the effect of surface preparation on the friction behaviour of a DLC coated tool material, we may conclude the following inferences:

The most important establishment is that the applied GBB surface preparation procedure provides better surface conditions in frictional applications, resulting in lower value of friction and better adhesion of the coating to the substrate as compared to the polishing preparation operation.
There was no distortion or damage to the coating i.e. the integrity of DLC layer was maintained along the entire sliding distance in case of GBB prepared samples.

The samples that were polished before the coating showed significant variation in the value of $\mu$ and abrupt changes in the slope of the friction coefficient curve along the entire sliding distance which indicates possibility of debris formation and partial detachment of the DLC coating.

In case of the uncoated samples that were simply nitrided, the surface was extremely rough, and the friction coefficient curve had varying amplitude with increasing slope.

Altogether if we conclude that for the case of the accomplished condition of the ball on disc test the most favourable combination of the surface preparation process is represented by the case, when GBB surface preparation is carried out prior to PECVD coating depositing a DLC layer on the surface of the investigated $\mathrm{X} 42 \mathrm{Cr} 13 / \mathrm{W}$ tool material.

\section{REMARK}

The paper was presented at the 17th Young researchers' conference, Materials Science and Engineering, Belgrade, December 5-7, 2018.

\section{ACKNOWLEDGEMENT}

This research was supported by the European Union and the Hungarian State, co-financed by the European Regional Development Fund in the framework of the GINOP-2.3.4-15-2016-00004 project, aimed to promote the cooperation between the higher education and the industry.

\section{REFERENCES}

[1] Mittemeijer E. J, Somers, M. A. J, Thermochemical Surface Engineering of Steels. Woodhead Publishing. ISBN: 978085709592, Chapter 1, pp. 23-25, 2014.

[2] Ahangarani, S, F. Mahboubi and A. Sabour, Effects of various nitriding parameters on active screen plasma nitriding behaviour of a low-alloy steel. Vacuum 80(9): pp.1032-1037, 2006.

[3] Bell T, H. Dong and Y. Sun, Realising the potential of duplex surface engineering. Tribology International 31(1-3): pp.127-137, 1998.

[4] Pye D, Practical Nitriding and Ferritic Nitrocarburizing. ASM International, ISBN: 0-87170-791-8, Chapter 1, pp.15-18, 2003. 
[5] Xu D. Z, Xiong F. F, Plasma Surface Metallurgy, Springer Nature, pp.12-18. DOI 10.1007/978-98110-5724-3_2, 2017.

[6] Xu D. Z, Liu X. P, Zhang P. Z, Double Glow Plasma Surface Alloying and Plasma Nitriding. Surface Coating Technology, pp. 22-35, 2007.

[7] Yagita K. Ohki C, Plasma Nitriding Treatment of High Alloy Steel for Bearing Components. NTN Technical Review No.78, pp. 2-6, 2010.

[8] Hainsworth N, Uhure J, Diamond-like carbon coatings for Tribology: Production Techniques, Characterisation Methods and Applications. International Materials Reviews, 52:3, pp.153-174, DOI: $10.1179 / 174328007 X 160272$

[9] AL Mahmud, K. A. H, et al, An Updated overview of Diamond - Like Carbon coating in Tribology. Critical Reviews in Solid State and Materials Science. ISSN 1040-8436. pp.1-29, 2014.
[10]Holmberg K, Matthews A, Coatings Tribology Properties, techniques and applications in surface engineering. Elsevier Tribology Ser. 28, Elsevier Science, the Netherlands, pp. 442, 1994.

[11]Caruta B. M, Thin Films and Coatings: New research. Nova Science Publishers, New York, ISBN 159454-517-0

[12]Siddiqui S. A, Biro A. Sz, Maros B. M. Characterization of the scratching behaviour of surface layers produced on $\mathrm{X} 42 \mathrm{Cr} 13$ steel by duplex heat treatment, Doktoranduszok Fóruma 2017: GÉIK szekciókiadványa (ISBN 978-963-358-166-7) (Conference Proc. of Doctoral Forum of UM, 2018) pp. 97-104, 2018.

[13]Siddiqui S. A, Biro A. Sz, Maros B. M, Wear behaviour of duplex (PN+PVD) layers produced on $\mathrm{X} 42 \mathrm{Cr} 13$ steel, Production Systems and Information Engineering, ISSN: 1785-1270 (in print)

[14]Anton Paar, CSM Instruments: Calotest Technical Features, Neuchâtel, 201.4

\section{SUMMARY}

\section{UTICAJ PRIPREME POVRŠINE NA PONAŠANJE NA TRENJE I HABANJE X42CR13 PLASTIČNOG KALUPA ALATNOG ČELIKA SA DLC PREMAZOM}

Cilj prikazanog istraživanja je da se ispita uticaj različitih priprema površine - peskarenje staklenim perlama $(G B B)$ i poliranje $(P)$ na ponašanje trenja kod dvostruko tretiranog, ugljenikom sa svojstvima dijamanta (DLC) Ks42Cr13 obloženog čeličnog alata. Dvostruki tretman je uključivao plazma nitriranje praćeno hemijskim taloženjem para pojačano plazmom (PECVD) i priprema površine je izvršena nakon nitriranja pre PECVD premaza. Ponašanje frikcije je ispitivano korišćenjem testa habanja lopte na disku, koji je odredio krive koeficijenta trenja u odnosu na klizno rastojanje, a morfologija tragova habanja ispitivana je optičkim mikroskopom. Na osnovu prikazanih eksperimentalnih rezultata utvrđeno je da GBB i postupci poliranja imaju značajno različit uticaj na ponašanje trenja $i$ habanja gornjeg sloja, što kao rezultat ima nižu vrednost koeficijenta trenja, manje habanje $i$ veće prijanjanje premaza na podlogu u slučaju GBB operacije. Pored toga, neki rezultati ispitivanja su prikazani za nepremazane, jednostavno nitrirane uzorke kako bi se naglasila prednost dvostrukog tretmana na ponašanje habanja / trenja ispitivanog materijala alata

Ključne reči: dvostruka površinska obrada, plazma nitriranje, DLC prevlačenje, test lopte na disku 